\title{
Basic Mechanisms of DNA-Raised Antibody Responses to Intramuscular and Gene Gun Immunizations
}

\author{
CHRISTINE M. BOYLE ${ }^{1}$ and HARRIET L. ROBINSON ${ }^{2}$
}

\begin{abstract}
DNA-raised antibody (Ab) responses have been compared for the dependence on $\mathrm{CD4}^{+}$and $\mathrm{CD8}^{+}$cells, the longevity of functional antigen (Ag) expression, and the nature of the Ag-presenting cell after intramuscular (IM) and gene gun inoculations. A plasmid expressing the hemagglutinin (HA) glycoprotein of influenza virus was used for immunizations of BALB/c mice. Intramuscular and gene gun-raised Abs had similar dependencies on $\mathrm{CD4}^{+}$and $\mathrm{CD8}^{+}$cells but different temporal patterns of functional Ag expression. The two methods of DNA immunization also appeared to have different frequencies or types of Ag-presenting cells in the draining lymph nodes and spleen. For both methods of DNA delivery, Ab was independent of $\mathrm{CD8}^{+}$cells but dependent on $\mathrm{CD4}^{+}$cells. The $\mathrm{CD} 4$ dependence occurred at priming but not booster immunizations and resulted in a 1-month delay in the Ab response. Temporal T-cell transfers from $\mathbf{T C R}^{+/+}$mice into immunized $\mathrm{TCR}^{-l-}$ mice revealed the persistence of DNA-expressed Ag for up to 1 month after both IM and gene gun inoculations. For gene gun, but not IM immunizations, approximately $90 \%$ of the functional Ag expression was lost by 1 week, consistent with the sloughing of the epidermal target site. Despite similar titers of raised Ab, Ag-presenting dendritic cells could be detected in the draining lymph nodes and spleen of gene gun- but not IM DNA-immunized mice. In the gene gun-immunized mice, Ag-presenting dendritic cells appeared in the draining lymph nodes before the spleen.
\end{abstract}

\section{INTRODUCTION}

D NA immunization is an effective means of raising longlived humoral and cellular immunity that is protective in a variety of preclinical models for viral, bacterial, and parasitic infections (Liu et al., 1998; Robinson and Pertmer, in press). Two frequently used methods of DNA immunization are delivery in saline by IM injections and the delivery of DNA-coated gold beads to the epidermis with a gene gun. For both of these methods, the vaccine plasmid and its expression can most easily be detected at the site of inoculation. After IM immunizations, expression in muscle, a stable tissue, has been reported for periods of time ranging from 1 month to as long as 1.5 years (Chattergoon et al., 1998; Wolff et al., 1990). After gene gun immunizations, expression in skin, which sheds its epidermis, peaks at 2 to 3 days and is largely lost by 2 weeks (Andree $e t$ al., 1994; Torres et al., 1997; Williams et al., 1991). For both
IM and gene gun immunizations, plasmid and plasmid expression have been detected in cells located in lymph nodes draining the muscle or skin target site (Casares et al., 1997; Chattergoon et al., 1998; Condon et al., 1996).

After DNA immunization s by either route, bone marrow-derived cells are responsible for presenting DNA-expressed Ag (Corr et al., 1996; Doe et al., 1996; Fu et al., 1997; Iwasaki et al., 1997). For gene gun immunizations, dendritic cells are Agpresenting cells (APCs) (Condon et al., 1996; Porgador et al., 1998). This is not surprising, as approxim ately $5 \%$ of the cells in the gene gun target are epidermal Langerhans cells (Stingl, 1990, which can carry DNA or Ag from the skin to the draining lymph nodes, where they differentiate to become dendritic cells (Banchereau and Steinman, 1998; Condon et al., 1996; Porgador et al., 1998; Warfel et al., 1993). Unlike the skin, the muscle target site has relatively few resident APCs (Hohlfeld and Engel, 1994). Also, within minutes of inoculation, the im-

${ }^{1}$ Department of Pathology, University of Massachusetts Medical School, Worcester, Massachusetts.

${ }^{2}$ Division of Microbiology and Immunology, Yerkes Regional Primate Research Center of Emory University, Atlanta, Georgia. 
mune response raised by IM delivery of DNA is independent of the muscle target (Torres et al., 1997). Therefore, transfection of cells trafficking through the muscle, or vaccine plasmids that move out of the muscle in lymph or blood to transfect distal cells, is likely to initiate the immune response. Thus, Ag presentation after IM delivery of DNA may take place in more than one lymphoid tissue and in more than one cell type. In support of this possibility, both dendritic cell and macrophages have been reported to be transfected and capable of specifically stimulating T cells after IM DNA immunizations (Casares et al., 1997; Chattergoon et al., 1998).

In this study, we used an influenza hemagglutinin (HA)-expressing vaccine plasmid to further investigate and compare the ability of gene gun and IM DNA immunizations to raise Ab. We determine how depletion of $\mathrm{CD}^{+}{ }^{+}$or $\mathrm{CD} 8^{+} \mathrm{T}$ cells at the time of DNA priming or booster immunizations affects the developing $\mathrm{Ab}$ response. We examine the duration of functional Ag expression, or how long an Ab response is capable of being initiated after delivery of the HA plasmid. Lastly, we address the role of dendritic cells in Ag presentation using specific stimulation of T-cell clones.

\section{MATERIALS AND METHODS}

Mice

Specific pathogen-free 6- to 8-week old female BALB/c mice were obtained from Taconic Farms (Tarrytown, NY). Female 5- to 8-week-old C57BL/6 and C57BL/6 TCR $\alpha / \beta$-/-, which have a targeted disruption in the $T C R \beta$ gene and therefore lack functional $\mathrm{T}$ cells (Mombaerts et al., 1992), were purchased from the Jackson Laboratories (Bar Harbor, ME). Mice were used in accordance with institutionally approved guidelines for animal care.

\section{DNA and HA protein vaccines}

An influenza A/PR/8/34 H1-expressing plasmid, pJW 4303/H1, was used for all DNA immunizations (Robinson et al., 1995). The plasmid was grown in HB 101 or DH5 $\alpha$ strains of E. coli and purified with Qiagen Giga Kits (Qiagen, Chatsworth, CA). DNA was dissolved in $1 \mathrm{mM}$ Tris and 0.1 $\mathrm{mM}$ EDTA, $\mathrm{pH} 8.0$, and stored at $-20^{\circ} \mathrm{C}$. A subunit vaccine of A/PR/8/34 was prepared by extracting the surface HA and neuraminidase (NA) Ags from influenza virus particles with the non-ionic detergent 7.5\% $N$-octyl- $b$-D-thioglucopyranos ide (Johansson and Kilbourne, 1993). The detergent-solubili zed virus was centrifuged, and the HA/NA-rich supernatant fluid $(\approx 55 \%$ HA) was used as the subunit vaccine. Single inoculations of 15 $\mu \mathrm{g}$ of the HA protein were administered in $50 \mu \mathrm{l}$ of saline to the quadricep muscle of the mice.

\section{DNA immunizations}

For gene gun immunizations, DNA was delivered to the shaved abdominal skin of ketamine/xylazine-anesthetiz ed mice using the helium-pulse Accell® gene gun (Powderject, Middleton, WI). pJW4303/H1 DNA was precipitated onto $0.95-\mu \mathrm{m}$ gold beads at $0.25 \mu \mathrm{g}$ of DNA per milligram of gold (Eisenbraun et al., 1993). Each shot contained $0.5 \mathrm{mg}$ of gold. Mice received either 4 or 10 nonoverlapping shots delivered with a helium discharge pressure of 400 to 450 psi. For IM immunizations, $100 \mu \mathrm{g}$ of pJW4303/H1 DNA was dissolved in 100 $\mu 1$ of saline, and a $50 \mu 1$ volume was injected into each surgically exposed quadriceps muscle.

\section{T-cell depletions}

$\mathrm{BALB} / \mathrm{c}$ mice were depleted in vivo of $\mathrm{CD} 4^{+}$and $\mathrm{CD} 8^{+} \mathrm{T}$ cells at prime or at boost using an ascites preparation of rat antimouse monoclonal antibodies, clones GK1.5 (Wilde et al., 1983) and Lyt2,43 (Sarmiento et al., 1980), respectively. For depletion of either population, ascites was used at a 1:5 dilution given every other day intraperitoneally (IP) in a 100- $\mu 1$ volume. The effectiveness of depletion was checked by flow cytometric staining of peripheral blood leukocytes. Depletion of $\mathrm{CD}^{+}{ }^{+}$cells was checked with Ab RMA4.4 FITC (Pharmingen, San Diego, CA), and depletion of $\mathrm{CD}^{+} \mathrm{T}$ cells was checked with Ab Lyt 2.2 PE (Pharmingen). Depleted mice were $98 \%$ to $99 \%$ free of $\mathrm{CD}^{+}$or $\mathrm{CD}^{+} \mathrm{T}$ cells. For both depletion at prime and depletion at boost, ascites was given from 3 weeks prior to 2 weeks after immunization (see Fig. 1 below).

T-cell transfers, TCR $\alpha / \beta^{+/+} \rightarrow T C R \alpha / \beta^{-/-}$

Nylon wool-enriched $\mathrm{T}$ cells from $\mathrm{TCR} \alpha / \beta^{+/+}$mice were transferred into TCR $\alpha / \beta^{-l-}$ mice on various days after immunization. Total $\mathrm{T}$ cells from the spleen of one TCR $\alpha / \beta^{+/+}$ mouse were transferred into a TCR $\alpha / \beta^{-1-}$ mouse via the tail vein in a volume of $200 \mu \mathrm{l}$ of serum-free RPMI 1640. Nylon wool enrichment of $\mathrm{T}$ cells was performed according to established protocols (Hathcock, 1998). In all cases, T cells were enriched to $65 \%$ or greater of the resulting population of cells.

\section{Dendritic cell purification and T-cell restimulation}

Dendritic cells $\left(\mathrm{CD} 11 \mathrm{c}^{+}\right)$were isolated on various days after gene tun or IM delivery of DNA to BALB/c mice. Pooled inguinal lymph nodes or spleens were teased apart in collagenase D 100 units/ml (Boehringer Mannheim, Indianapolis, IN). The cell suspension was vigorously pipetted and the cells collected after passage through nylon mesh. The remaining tissue was incubated in collagenase D 400 units $/ \mathrm{ml}$ at $37^{\circ} \mathrm{C}$ for 30 min. After vigorous pipetting, the suspension was again passed through nylon mesh. Cells were centrifuged and resuspended in $5 \mathrm{ml}$ of dense BSA (Intergen, Purchase, NY) layered with 1 to $2 \mathrm{ml}$ of $\mathrm{Ca}^{++}$- and $\mathrm{Mg}^{++}$-free Hank's balanced salt solution (HBSS; GIBCO/BRL, Grand Island, NY) and centrifuged at $1000 \mathrm{rpm}$ for $30 \mathrm{~min}$. The low-density cells were removed, washed in $\mathrm{Ca}^{++}$- and $\mathrm{Mg}^{++}$-free $\mathrm{HBSS}$, and stained with phycoerythrin-labeled CD11c (Pharmingen). The cells were sorted into $\mathrm{CD}_{11 \mathrm{c}^{+}}$and $\mathrm{CD} 11 \mathrm{c}^{-}$populations. The $\mathrm{CD} 11 \mathrm{c}^{+}$population was $>85 \%$ pure and the $\mathrm{CD}_{11 \mathrm{c}^{-}}$population $>99 \%$ pure. Sorted populations were used in restimulation assays of T-cell clones.

Two HA-specific CD4 ${ }^{+}$T-cell clones, kindly provided by Dr. Walter Gerhard (Wistar Institute, Philadelphia, PA), were used to assess presentation of DNA-expressed HA Ag by sorted CD 11 $\mathrm{c}^{+}$and CD11 $\mathrm{c}^{-}$populations. Clone T4, 5.1-6R6.3, is specific for site 2 of HA presented by I-A ${ }^{\mathrm{d}}$; and clone T20, 5.11R20, is specific for site 3 of HA (Scherle, 1988). Both clones 
produce interferon gamma (IFN- $\gamma$ ) on restimulation. Cells of either clone $\left(2 \times 10^{4}\right)$ were added to the wells of U-bottom 96well tissue culture plates in which sorted dendritic $\left(\mathrm{CD} 11 \mathrm{c}^{+}\right)$ and non-dendritic $\left(\mathrm{CD} 11 \mathrm{c}^{-}\right)$cell populations had been added in twofold serial dilutions. After $48 \mathrm{~h}$, the supernatant liquid was removed, and IFN- $\gamma$ production was assessed by ELISA (see below). There was no difference in background stimulation according to whether cells were isolated from naive nonimmunized mice or from mice immunized with control vectors without a vaccine insert (data not shown).

\section{HA-specific IgG ELISA}

The concentrations of HA-specific IgG in mouse sera were quantitated by ELISA. Wells of a 96-well ELISA plate (Corning, Corning, NY) were coated overnight at $4{ }^{\circ} \mathrm{C}$ with $200 \mathrm{HA}$ units of lysed A/PR/8/34(H1N1) in carbonate buffer per well. Nonspecific binding was blocked by incubation with $1 \%$ BSA (Sigma Chemical Co., St. Louis, MO) in PBS. Serum samples were diluted in PBS containing 0.1\% Tween-20 (Sigma) and $0.5 \%$ BSA (Sigma). Anti-H1 IgG was detected with horseradish peroxidase-labeled goat anti-mouse $\operatorname{IgG}(\mathrm{H}+\mathrm{L}$ ) (Southern Biotechnology, Birmingham, AL) and developed with ABTS substrate (Sigma). Plates were read at $405 \mathrm{~nm}$ and analyzed using Softmax 2.3 (Molecular Devices, Menlo Park, CA). Quantitation of $\mathrm{H} 1$-specific $\mathrm{IgG}$ was made by comparison with a standard curve of purified mouse IgG captured with an antimouse Fab (Southern Biotechnology) that was run for each ELISA and detected with goat anti-mouse $\operatorname{IgG}(\mathrm{H}+\mathrm{L})$ as above.

\section{IFN- $\gamma$ ELISA}

The IFN- $\gamma$ in the supernatant fluid of restimulated T-cell clones was quantitated by ELISA. Wells of a 96-well plate (Corning) were coated overnight at $4^{\circ} \mathrm{C}$ with $100 \mu \mathrm{l}$ of anti-IFN $\gamma \mathrm{Ab} 2 \mu \mathrm{g} / \mathrm{ml}$ (Pharmingen) diluted in carbonate buffer. Plates were washed with PBS-0.1\% Tween-20, and nonspecific binding was blocked with PBS-10\% fetal bovine serum (FBS; GIBCO/BRL) for $1 \mathrm{~h}$ at $37^{\circ} \mathrm{C}$. Samples were added to wells in PBS-10\% FBS, serially diluted with twofold dilutions, and incubated at room temperature for $4 \mathrm{~h}$. Plates were washed three times with PBS plus $0.1 \%$ Tween 20 , and biotinylated anti-IFN$\gamma(1 \mu \mathrm{g} / \mathrm{ml})$ was added to each well. The plates were incubated at room temperature for $1 \mathrm{~h}$. Plates were washed, a 1:1000 dilution of horseradish peroxidase-conjug ated avidin in PBS-10\% FBS was added, and then incubated at room temperature for $1 \mathrm{~h}$. Plates were washed and peroxidase developed with ABTS substrate (Sigma). Plates were read at $405 \mathrm{~nm}$ and analyzed using Softmax 2.3. The IFN- $\gamma$ was quantitated by comparison with a standard curve of purified IFN- $\gamma$ (Pharmingen) captured and detected as above with the ABTS substrate.

\section{RESULTS}

\section{Ab responses in mice depleted of $\mathrm{CD}^{+}$or $C D 8^{+} \mathrm{T}$ cells}

To assess the role that $\mathrm{CD}^{+}$and $\mathrm{CD} 8^{+} \mathrm{T}$ cells play in the $\mathrm{Ab}$ responses raised by DNA immunization, mice were depleted with either anti-CD4 or anti-CD8 antibodies at the time of prime or boost (Fig. 1). The T cells were depleted for 3 weeks prior to through 2 weeks after DNA priming or booster immunizations. For depletion at priming, mice were immunized with high doses of DNA: $0.4 \mu \mathrm{g}$ by gene gun and $100 \mu \mathrm{g}$ by the IM route. For depletion at booster immunizations, mice were primed with low doses of DNA $-0.04 \mu \mathrm{g}$ by gene gun and $5 \mu \mathrm{g} \mathrm{IM}-$ and boosted with a 20 -fold higher dose of DNA $-0.8 \mu \mathrm{g}$ or 100 $\mu \mathrm{g}$, respectively - to ensure a strong boost. These high and low doses of DNA lie at the upper and lower ends of the range of DNA doses that score on the linear portion of a dose-response curve following a single DNA immunization.

The depletion of $\mathrm{CD} 4^{+} \mathrm{T}$ cells at the time of priming resulted in a temporary delay of the $\mathrm{Ab}$ response following both gene gun (Fig. 2A) and IM (Fig. 2C) DNA immunizations. At 4 weeks after priming, anti-HA $\operatorname{IgG}$ was present in nondepleted mice but was undetectable in CD4-depleted mice (Fig. 2A, C). However, by 8 weeks, 5 of 6 mice in both the gene gun- and IM-immunized and CD4-depleted groups had HA-specific Ab. The magnitude of this $\mathrm{Ab}$ response was approximately 16-fold lower than in the nondepleted controls for gene gun immunizations and 9-fold lower than in the nondepleted controls for IM immunizations (Fig. 2A, C). This delay in the response suggested that functional $\mathrm{Ag}$ expression from the immunizing DNA had continued beyond the period of depletion and had primed $\mathrm{CD}^{+} \mathrm{T}$ cells as they reappeared in the mice.

In contrast to the results of the $\mathrm{CD} 4^{+}$depletion at prime, depletion of $\mathrm{CD}^{+}$cells at the time of DNA boost had no apparent effect on the $\mathrm{Ab}$ response. For gene gun immunization, the $\mathrm{Ab}$ response was boosted approximately sixfold in the nondepleted control group and ninefold in the CD4-depleted group (Fig. 2B). For IM immunization, the Ab response was boosted approximately sevenfold in both the nondepleted and CD4-depleted groups (Fig. 2D).

The absence of $\mathrm{CD} 8^{+} \mathrm{T}$ cells at the time of DNA prime or boost did not affect the Ab response (Fig. 2E-H). With $\mathrm{CD} 8^{+}$ depletion at prime, similar levels of $\mathrm{Ab}$ were raised in the depleted and nondeleted groups with both gene gun and IM im-

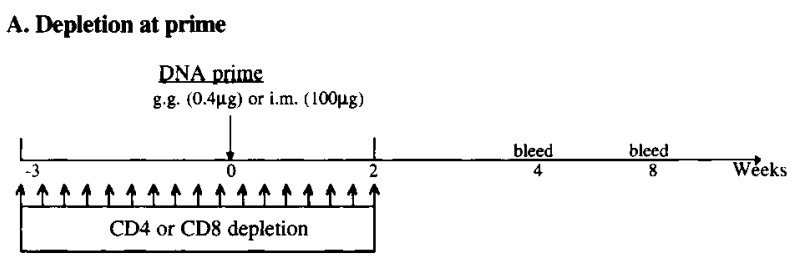

\section{B. Depletion at Boost}

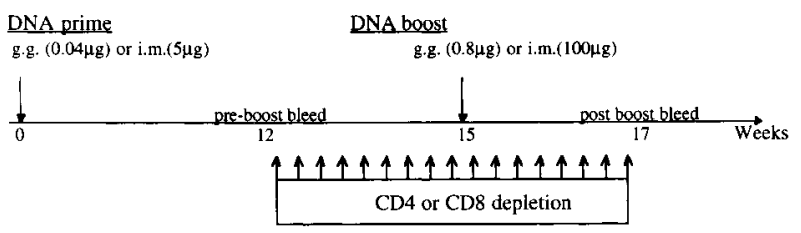

FIG. 1. Schematic for experiment examining the role of $\mathrm{CD}^{+}{ }^{+}$or $\mathrm{CD}^{+} \mathrm{T}$ cells for the DNA-raised anti-HA Ab response. $\uparrow$ represents each time depleting $\mathrm{Ab}$ was given. g.g. $=$ gene gun immunization; i.m. = intramuscular immunization. 

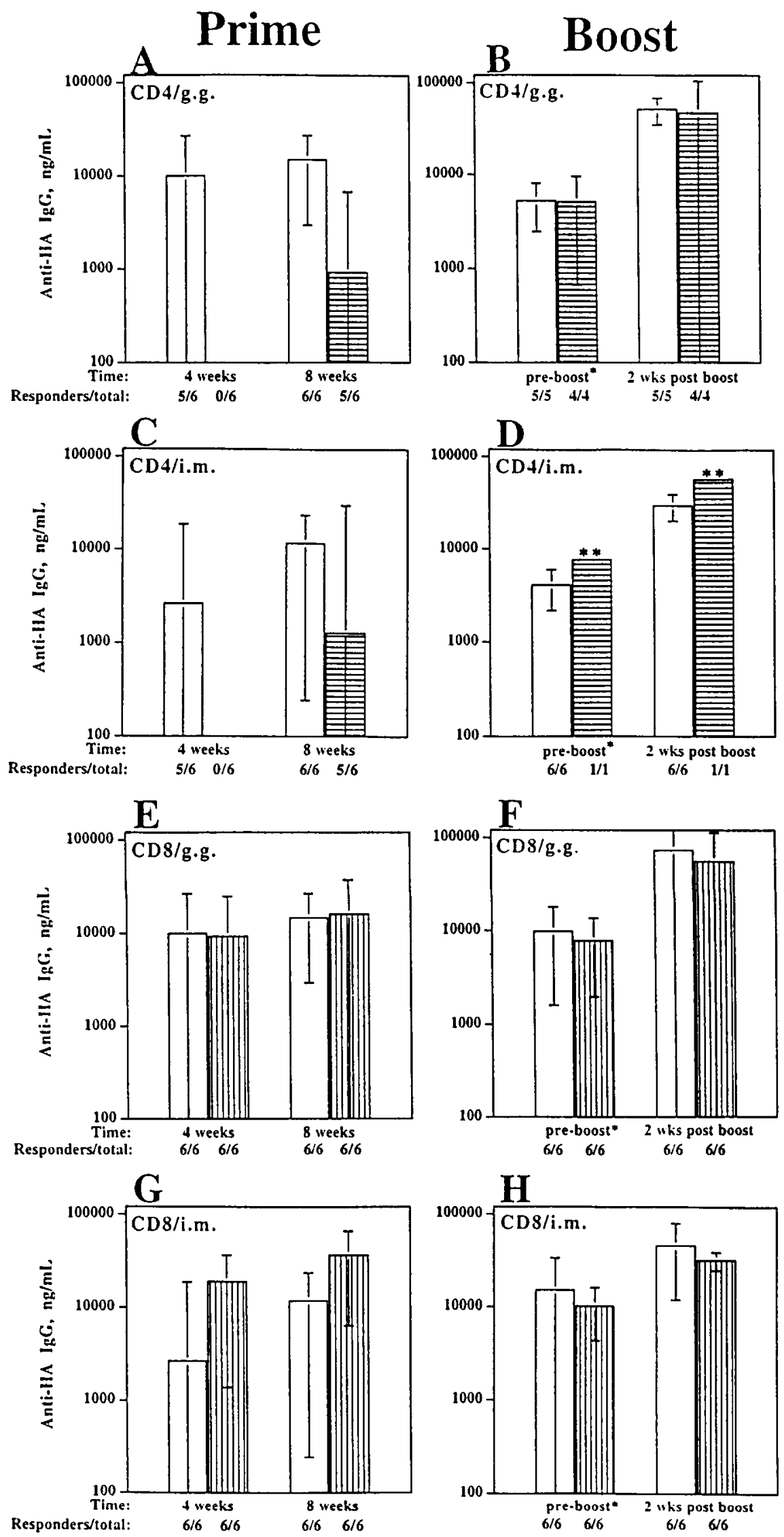
munizations (Fig. 2E, G). With $\mathrm{CD}^{+}$depletion at boost, the $\mathrm{Ab}$ response was boosted approximately sevenfold whether or not $\mathrm{CD}^{+} \mathrm{T}$ cells were present for gene gun immunization s and twofold to threefold whether or not $\mathrm{CD} 8^{+} \mathrm{T}$ cells were present for IM immunizations (Fig. 2F, H).

\section{Use of $T C R^{-/-}$mice to examine functional Ag expression after DNA immunization}

To more rigorously examine the duration of functional Ag expression for the initiation of an Ab response, TCR $\alpha / \beta$-knockout mice $\left(\mathrm{TCR}^{-1-}\right.$ ) were immunized with DNA. On various days after immunization, naive $\mathrm{T}$ cells from the spleens of agematched TCR $\alpha / \beta$-positive mice $\left(\mathrm{TCR}^{+/+}\right.$) were transferred into the immunized $\mathrm{TCR}^{-1-}$ mice (for schematic, see Fig. 3). The presence of functional DNA-expressed Ag was assessed by testing for HA-specific IgG at 4 weeks after the T-cell transfer. An HA protein immunization was included to compare the duration of functional Ag after DNA and protein immunizations.

$\mathrm{T}$-Cell transfer experiments in gene gun-immunized mice revealed functional $\mathrm{Ag}$ expression for at least 1 month (Fig. 4). No HA-specific IgG was detected in gene gun- immunized $\mathrm{TCR}^{-1-}$ mice that did not receive $\mathrm{T}$ cells (Fig. 4A). Sixteen of the seventeen mice given $\mathrm{T}$ cells on the day of immunization or 2 or 3 days after immunization raised $\mathrm{Ab}$ responses comparable to those in immunized $\mathrm{TCR}^{+1+}$ mice. The HA-specific $\mathrm{Ab}$ also was raised when $\mathrm{T}$ cells were transferred 7,14 , or 28 days after gene gun immunization (Fig. 4A). However, the titers of $\mathrm{Ab}$ raised in groups receiving $\mathrm{T}$-cell transfers at days 7 and 14 were approximately 25 -fold lower than in $\mathrm{TCR}^{+/+}$mice. Following transfers at 28 days postimmunization, three of five mice were still able to raise specific $\mathrm{Ab}$, but at a much lower level (approximately 500 times lower) than in $\mathrm{TCR}^{+/+}$mice. In sum, these data indicate that gene gun-immunized mice lost functional Ag with time and are consistent with keratinocytes at the skin target site playing a role as factories for Ag production during the 1st week postimmunization (Klinman et al., 1998; Torres et al., 1997).

T-Cell transfers to the IM-immunized mice also revealed prolonged presence of functional Ag. As in the gene gun immunizations, no $\mathrm{Ab}$ was raised in $\mathrm{TCR}^{-1-}$ mice that did not receive $\mathrm{T}$ cells. However, in mice that received $\mathrm{T}$ cells on the day of immunization, or at 2 or 7 days after IM immunization, HAspecific $\mathrm{Ab}$ was raised in all 20 mice, with the titers being similar to those in $\mathrm{TCR}^{+/+}$mice (Fig. 4B). When $\mathrm{T}$ cells were transferred 28 days after IM delivery of DNA, no HA-specific $\mathrm{Ab}$ was detected (Fig. 4B). This result is similar to the result seen with gene gun immunization in that the ability to raise an $\mathrm{Ab}$ response was lost by 1 month postimmunization. However, gene gun and IM immunizations differed in that at day 7 , the magnitude of the $\mathrm{Ab}$ response had decreased in the gene gun-

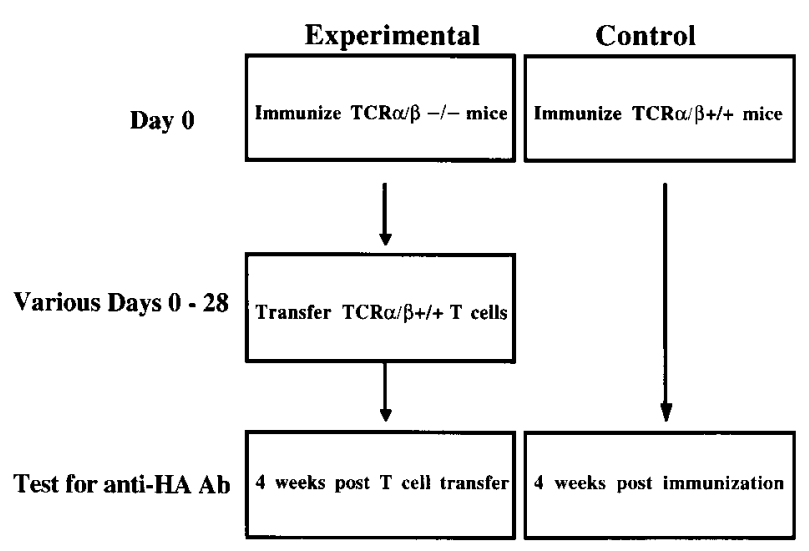

FIG.3. Schematic of test for the longevity of functional DNA expression. For details, see Materials and Methods.

immunized mice but not in the IM-immunized mice (Fig. 4A, B).

In contrast to DNA immunizations, after protein immunization, functional Ag had largely been lost by 7 days (Fig. 4C). The $\mathrm{TCR}^{-1-}$ mice that received $\mathrm{T}$ cells on the day of immunization produced high titers of $\mathrm{Ab}$. The level of the Ab response in this group was comparable to that in the $\mathrm{TCR}^{+/+}$control group. With transfer 7 days after protein immunization, only one of the five tested mice had detectable anti-HA IgG. Thus, by 1 week, most of the immunizing protein was no longer available for priming $\mathrm{T}$ cells.

\section{Presence and persistence of Ag-presenting dendritic cells after DNA immunization}

To examine the role of dendritic cells in Ag presentation after DNA immunization, populations of cells with the CD11c ${ }^{+}$ marker for dendritic cells were sorted from lymph nodes draining the immunization site and tested for their ability to present DNA-expressed Ag to two HA-specific $\mathrm{CD}^{+}{ }^{+} \mathrm{T}$-cell clones. The sorted populations were at least $85 \%$ pure $\mathrm{CD}_{11 \mathrm{c}^{+}}$and 99\% pure CD11c ${ }^{-}$cells (Fig. 5). Forty-eight hours later, culture supernatant liquids were tested for IFN- $\gamma$ production. Stimulation was considered to be HA-specific if the amount of IFN$\gamma$ produced by either $\mathrm{T}$-cell clone was at least twofold greater for at least two dilutions of cells sorted from HA DNA-immunized mice than for cells sorted from naive or control DNAimmunized mice.

Figure 6A shows an example of specific restimulation of the $\mathrm{T} 4$ clone by $\mathrm{CD} 11 \mathrm{c}^{+}$cells sorted from the inguinal lymph nodes of gene gun-immunized mice. Figure $6 \mathrm{~B}$ shows that $\mathrm{CD} 11 \mathrm{c}^{+}$ cells isolated from inguinal lymph nodes of gene gun-immu-

FIG. 2. Depletion of $\mathrm{T}$ cells at DNA immunization or boost. Mice were depleted of $\mathrm{CD} 4^{+}$(horizontally hatched bars) or CD $8^{+}$ (vertically hatched bars) T cells at the time of DNA prime (A, C, E, G) or at the time of DNA boost (B, D, F, H). The pJW4303/H1 DNA was delivered either by gene gun (g.g.; A, B, E, F) or intramuscularly (i.m.; C, D, G, H). Amounts of HA-specific IgG in the sera of immunized mice were determined by ELISA. Data are the means \pm SEM of HA-specific IgG. The number of mice with detectable $\mathrm{Ab}$ in each group is given as responders/total. *Preboost, HA-specific IgG titers at plateau of primary response before mice were given any depleting antibodies; **only 1 mouse of 6 tested had depletion of $>98 \%$ at the time of DNA boost. White bars $=$ control/ not depleted. 


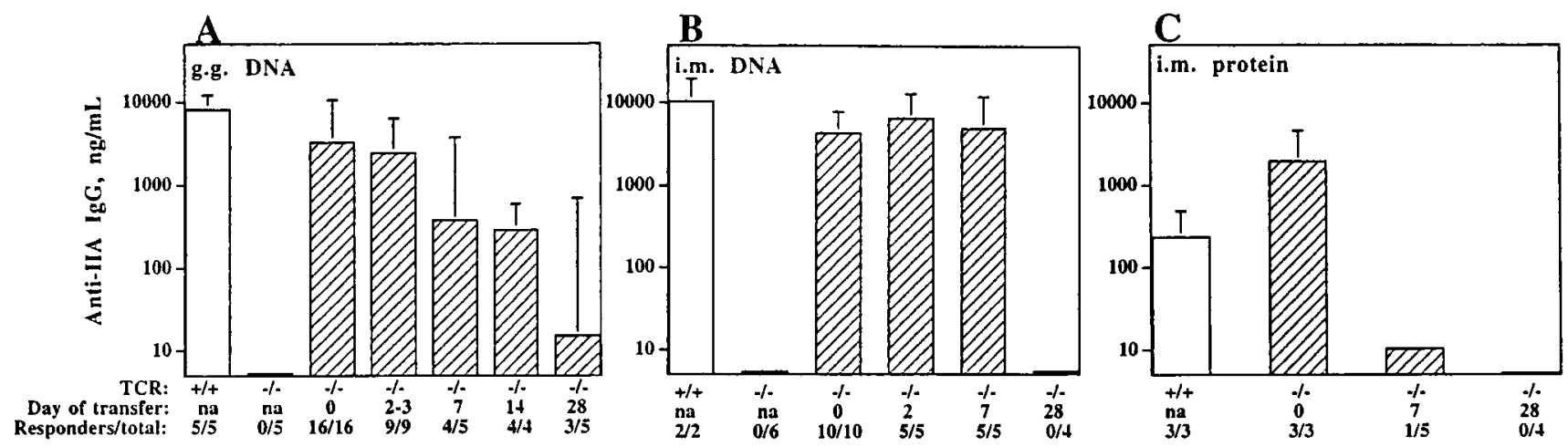

FIG. 4. Time course of functional antigen expression after DNA and protein immunizations. Mice were immunized with either HA-DNA via gene gun (A) or intramuscular (B) deliveries of DNA or HA protein (C). Data are the means \pm SEM of HAspecific IgG. The number of mice with detectable $\mathrm{Ab}$ in each group is given as responders/total. White bars $=\mathrm{Tcr}{ }^{+/+}$mice; hatched bars $=\mathrm{TCR}^{-1-}$ mice. g.g. = gene gun; i.m. = intramuscular.

nized mice restimulating the T20 clone. Figure $6 \mathrm{C}$ shows restimulation of the $\mathrm{T} 4$ clone by $\mathrm{CD} 11 \mathrm{c}^{+}$cells sorted from the spleens of HA-immunized mice. Control experiments comparing restimulation in naive and control DNA-treated mice revealed no restimulation of the $\mathrm{T}$-cell clones by mice exposed to vector DNA without the insert (data not shown).

The restimulation experiments revealed Ag presentation by CD $11 c^{+}$dendritic cells after gene gun but not IM deliveries of DNA (Table 1). After gene gun immunization, the HA-specific restimulatory activity was present for at least 21 days (Table 1). This activity was found in the $C D 11 \mathrm{c}^{+}$but not the CD $11 \mathrm{c}^{-}$ cells. In the majority of experiments (days 3, 5, 6, 7, 14, and 18), Ag-presenting $\mathrm{CD} 11 \mathrm{c}^{+}$cells were present in the draining lymph nodes. In two experiments, at 14 and 21 days, the HAspecific stimulatory $\mathrm{CD}_{11 \mathrm{c}^{+}}$populations were isolated from the spleen. In contrast, after IM delivery of HA DNA, HA-specific stimulatory activity was not detected (Table 1). This was true for assays performed from 2 to 7 days postimmunization on $\mathrm{CD} 11 \mathrm{c}^{+}$and $\mathrm{CD} 11 \mathrm{c}^{-}$cells from inguinal lymph nodes and spleen.
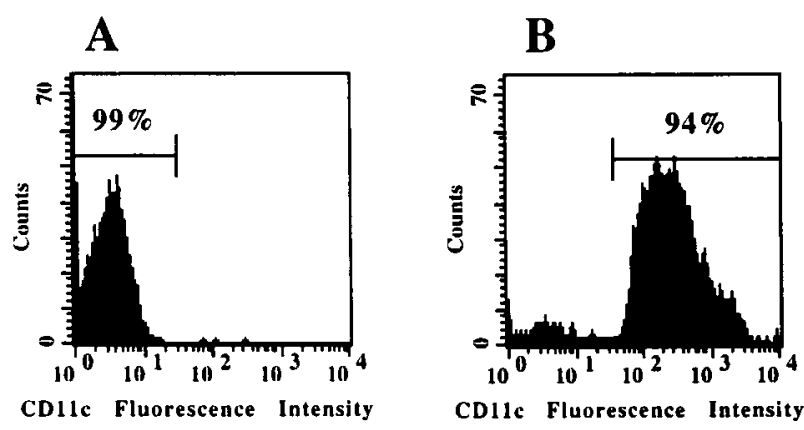

FIG. 5. Representative example of the purity of FACS CD11c cells from inguinal lymph nodes of DNA-immunized mice. (A) $\mathrm{CD}_{11 \mathrm{c}^{-}}$non-dendritic cell population (99\% purity). (B) $\mathrm{CD}_{11 \mathrm{c}^{+}}$dendritic cell population (94\% purity).

\section{DISCUSSION}

We have examined the role of $\mathrm{CD}^{+}$and $\mathrm{CD} 8^{+} \mathrm{T}$ cells, the persistence of functional $\mathrm{Ag}$, and the nature of the APC after gene gun and IM immunization with an HA-expressing DNA. Depletion of $\mathrm{CD}^{+}$or $\mathrm{CD}^{+} \mathrm{T}$ cells at the time of priming demonstrated the dependence of the DNA-raised $\mathrm{Ab}$ response on the former but not the latter (see Figure 2). Transfer of naive $\mathrm{T}$ cells from $\mathrm{TCR}^{+1+}$ mice into DNA-immunized $\mathrm{TCR}^{-1-}$ animals at various times revealed functional Ag persisting for as long as 1 month after DNA but not protein immunizations (see Fig. 4). In sorted populations of cells from lymphoid tissues, we readily detected Ag-presenting dendritic cells after gene gun but not IM DNA immunizations (see Table 1 and Fig. 6). We discuss these phenomena below.

\section{Persistence of functional Ag expression}

The persistence of functional DNA-expressed Ag was different in mice receiving gene gun and IM DNA immunizations (see Fig. 4A, B). Transfer of $\mathrm{T}$ cells from $\mathrm{TCR}^{+/+}$mice into immunized $\mathrm{TCR}^{-1-}$ mice revealed that by 1 week postimmunization, approximately $95 \%$ of the Ab response had been lost in gene gun DNA-immunized mice but not in IM-immunized mice. By 1 month, the ability to raise Ab had been lost in IMimmunized animals and was near background in gene gun-immunized mice. The early loss of a portion of the gene gun-raised response is consistent with both short-lived ( $<1$ week) and long-lived cells expressing functional Ag. For both methods of DNA immunization, Ag presentation is by professional APCs (Corr et al., 1996; Doe et al., 1996; Fu et al., 1997; Iwasaki et al., 1997). These cells can be directly transfected with DNA (Chattergoon et al., 1998; Condon et al., 1996; Porgador et al., 1998) or can acquire the DNA-expressed Ag produced by nonprofessional APCs (Doe et al., 1996; Fu et al., 1997). For the gene gun target, epidermal Langerhans cells represent the major source of transfected professional APCs (Codon et al., 1996; Porgador et al., 1998). These could be the long-lived APCs. Keratinocytes, which are largely shed within 1 week secondary to the natural sloughing of the epidermis, could represent the short-lived cells (Eisenbraun et al., 1993; Hengge et al., 1995; 


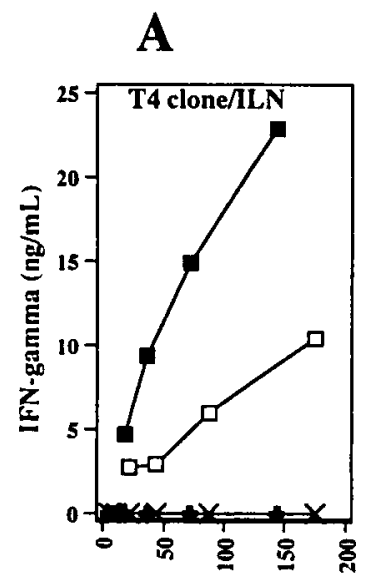

Number of sorted cells $(\mathbf{x 1 0 0 0 )}$

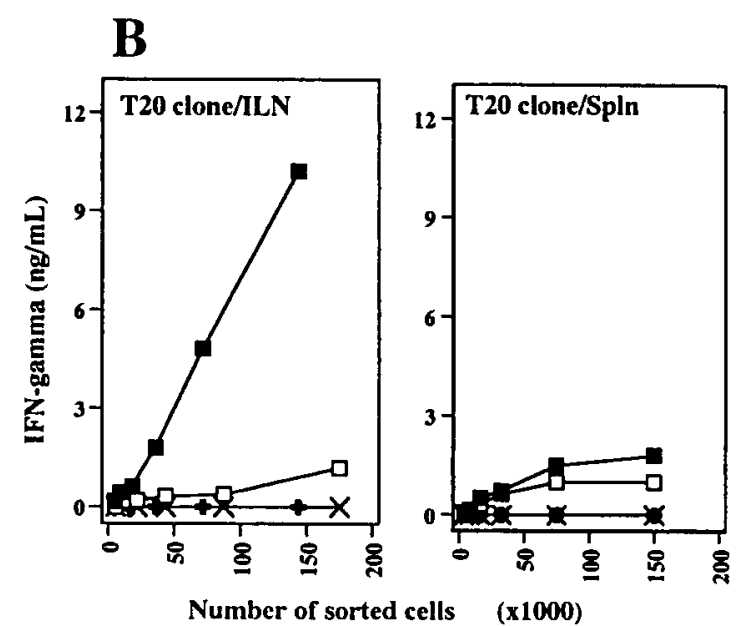

FIG. 6. Production of IFN- $\gamma$ by T-cell clones restimulated with sorted cells from the inguinal lymph nodes (ILN) or spleens (Spln) of gene gun-immunized mice. Dendritic cells were sorted from naive (no DNA) or gene gun (HA DNA)-immunized mice at 5 days $(\mathbf{A}, \mathbf{B})$ or 14 days (C) after immunization. (A) The T4 T-cell clone stimulated with cells sorted from inguinal nodes. (B) The T20 T-cell clone stimulated with cells sorted from inguinal nodes and spleen. (C) The T4 T-cell clone stimulated with cells sorted from spleen. $\square=$ HA DNA/CD $11 \mathrm{c}^{+} ; \square=$ no DNA/CD $11 \mathrm{c}^{+} ; \boldsymbol{+}=\mathrm{HA} \mathrm{DNA} / \mathrm{CD} 11 \mathrm{c}^{-} ; \mathrm{X}=$ no DNA/CD $11 \mathrm{c}^{-}$.

Klinman et al., 1998; Raz et al., 1994; Torres et al., 1997). For the muscle target, directly transfected dendritic cells or macrophages could represent long-lived sources of Ag (Casares et al., 1997; Chattergoon et al., 1998). Transfected muscle cells, as well as transfected cells distal to the site of inoculation, also could represent long-term factories of Ag (Doe et al., 1996). At least in mice, transfected cells distal to the muscle appear to be the primary factories of $\mathrm{Ag}$ because the muscle target is irrelevant to the magnitude of the $\mathrm{Ab}$ response within $10 \mathrm{~min}$ of DNA inoculation (Torres et al., 1997).

T-Cell transfers were also done into HA-protein immunized mice (see Fig. 4). In contrast to the DNA immunizations, after HA-protein immunization, the capability to raise Ab was largely lost within 1 week (Fig. 4C). This difference is likely to reflect the shorter presence of the immunogen after protein than DNA immunizations because of the continued expression of the immunizing plasmid. Thus, our data support the hypothesis that persistent expression of a vaccine DNA contributes to the ability of DNA-expressed immunogens to initiate and maintain $\mathrm{Ab}$ responses.

\section{Nature of the APC}

Antigen-presenting dendritic cells were detected after gene gun but not IM DNA immunizations (see Fig. 6; Table 1). After gene gun immunizations, Ag-presenting dendritic cells appeared in the draining lymph nodes by 3 days (Table 1). The earliest time at which APC were detected in the spleen was 14 days. This time course would be consistent with gene gun-raised Ag presentation being initiated in the draining lymph nodes but with time, in some instances, moving to the spleen.

After IM immunizations, we were unable to detect HA presentation by the sorted dendritic $\left(\mathrm{CD} 11 \mathrm{c}^{+}\right)$or non-dendritic $\left(\mathrm{CD} 11 \mathrm{c}^{-}\right.$) cell populations (Table 1). Antibody responses reached similar levels after gene gun and IM inoculations of the HA-expressing DNA (see Fig. 2). Therefore, the inability
Table 1. IFN- $\gamma$ Production after Restimulation of HASpecific T-Cell Clones by Cells Sorted from Inguinal Lymph Nodes or Spleens of HA-DNA Immunized Mice ${ }^{\text {a }}$

\begin{tabular}{|c|c|c|c|c|}
\hline \multirow[b]{2}{*}{$D a y^{\mathrm{b}}$} & \multicolumn{2}{|c|}{ Inguinal Nodes ${ }^{\mathrm{c}}$} & \multicolumn{2}{|c|}{ Spleen $^{\mathrm{c}}$} \\
\hline & $C D 11 c^{+}$ & $C D 11 c^{-}$ & $C D 11 c^{+}$ & $C D 11 c^{-}$ \\
\hline \multicolumn{5}{|l|}{ Gene gun } \\
\hline 3 & $2 / 2$ & $0 / 2$ & $0 / 1$ & $0 / 1$ \\
\hline 5 & $1 / 1$ & $0 / 1$ & $0 / 1$ & $0 / 1$ \\
\hline 6 & $2 / 2$ & $0 / 2$ & $0 / 1$ & $0 / 1$ \\
\hline 7 & $2 / 2$ & $0 / 2$ & $0 / 2$ & $0 / 2$ \\
\hline 14 & $1 / 2$ & $0 / 2$ & $1 / 2$ & $0 / 2$ \\
\hline 18 & $1 / 1$ & $0 / 1$ & $0 / 1$ & $0 / 1$ \\
\hline 21 & $0 / 2$ & $0 / 2$ & $1 / 1$ & $0 / 1$ \\
\hline Total $^{\mathrm{d}}$ & $9 / 12$ & $0 / 12$ & $2 / 9$ & $0 / 9$ \\
\hline \multicolumn{5}{|c|}{ Intram uscular } \\
\hline 2 & $0 / 1$ & $0 / 1$ & $0 / 1$ & $0 / 1$ \\
\hline 3 & $0 / 1$ & $0 / 1$ & $0 / 1$ & $0 / 1$ \\
\hline 5 & $0 / 2$ & $0 / 2$ & $0 / 2$ & $0 / 2$ \\
\hline 7 & $0 / 1$ & $0 / 1$ & $0 / 1$ & $0 / 1$ \\
\hline Total $^{\mathrm{d}}$ & $0 / 5$ & $0 / 5$ & $0 / 5$ & $0 / 5$ \\
\hline
\end{tabular}

${ }^{a}$ Mice were immunized with $1.25 \mu \mathrm{g}$ of pJW 4303/H1 DNA by gene gun (10 shots of $0.125 \mu \mathrm{g}$ per shot) or $100 \mu \mathrm{g}$ of pJW4303/H1 DNA delivered intramuscularly.

${ }^{b}$ Day after delivery of DNA on which lymphoid tissues were harvested.

${ }^{\mathrm{c}} \mathrm{CD} 11 \mathrm{c}^{+}$(dendritic) and $\mathrm{CD} 11 \mathrm{c}^{-}$(non-dendritic) cell populations sorted from pooled inguinal lymph nodes or spleens were used in stimulation assays with either of two HA-specific $\mathrm{CD} 4^{+} \mathrm{T}$-cell clones. Production of IFN- $\gamma$ was measured at $48 \mathrm{~h}$. Clones were considered to be specifically restimulated if the ratio of IFN- $\gamma$ production with HA-immunized sorted cells to that in nonimmunized naive sorted controls was $>2.0$. Results are shown as number of experiments with positive restimulation/ number of experiments done.

${ }^{\mathrm{d}}$ Total number of positive experiments/total number of experiments done with each lymphoid tissue. 
to detect Ag presentation was not attributable to a lower Ab response.

There are several possible explanations for our inability to detect Ag presentation after IM delivery of DNA. The first is that the frequencies of HA-presenting dendritic cells were below our level of detection. After IM immunization, DNA moves rapidly throughout the body (Winegar et al., 1996), and the immunologically relevant transfections take place outside the target site (Torres et al., 1997). This movement of DNA could lead to a broader distribution of APCs in lymphoid tissues than follows the more focused delivery of DNA by gene gun inoculations. Our assays could have detected HA-presenting cells at one fourth the frequency of those present in the draining lymph nodes of the gene guns-inoculated mice, suggesting that if HA-presenting dendritic cells were present after IM immunizations, they were present in amounts of $>4$ times lower than in the gene gun groups (Fig. 6). One group of investigators has detected Ag presentation by dendritic cells after IM DNA immunization (Casares et al., 1997). Their experiments differed from ours in using a different plasmid, a more sensitive T-cell hybridoma assay, and the delivery of two doses of DNA within 2 days prior to harvesting of the draining lymph nodes.

A second possible reason for our inability to detect HA presentation in IM-immunized mice is that APCs in these mice have different properties than those in gene gun-immunized mice. For gene gun immunizations, the dendritic cells that present Ag have differentiated from epidermal Langerhans cells (Condon et al., 1996; Porgador et al., 1998). For IM immunization, the origin of the dendritic cells that present $\mathrm{Ag}$ is not known. In addition, the mechanism by which vaccine plasmid is acquired by a dendritic cell is different in gene gun and IM immunizations. Gene gun immunizations deliver DNA into the cell on a gold bead, whereas after IM injection, DNA is taken up by cells from the extracellular milieu. This uptake may result in the triggering of different signaling cascades with different consequences for the differentiated state of the Ag-presenting dendritic cell (Jacob et al., 1998; Sparwasser et al., 1998). A third possibility is that after IM immunizations, nondendritic cells contribute to Ag presentation. Indeed, one group has reported that macrophages contain, express, and present IMdelivered DNA vaccines (Chattergoon et al., 1998).

\section{Role of $\mathrm{CD}^{+}$and $\mathrm{CD}^{+} \mathrm{T}$ cells}

The ability to raise $\mathrm{Ab}$ was dependent on the presence of $\mathrm{CD}^{+}$cells at the time of prime, but not boost, and independent of the presence of $\mathrm{CD} 8^{+} \mathrm{T}$ cells (see Fig. 2). Because the influenza HA protein is a T-cell-dependen $\mathrm{Ag}$, the dependence of the $\mathrm{Ab}$ response on the help of $\mathrm{CD}^{+}$cells is not surprising (Burns et al., 1975; Scherle and Gerhard, 1986). The fact that the $\mathrm{Ab}$ response was effectively boosted in CD4-depleted mice is perplexing. Perhaps the level of depletion, $98 \%$ to $99 \%$, was not sufficient to eliminate help for a memory B-cell response.

For both immunization and boost, depletion of $\mathrm{CD}^{+} \mathrm{T}$ cells did not alter the $\mathrm{Ab}$ responses (see Fig. 1E-H). We had hypothesized that $\mathrm{CD}^{+} \mathrm{T}$ cells raised by DNA priming would limit the effectiveness of the booster immunization by killing Ag-expressing cells. The $\mathrm{CD}^{+}$cells also could limit Ag expression by downmodulating the activity of the cytomegalovirus promoter by the production of interferons (Harms and
Splitter, 1995). Our results suggest that, at least for our plasmid vector, $\mathrm{CD} 8^{+}$cells did not limit functional $\mathrm{Ag}$ expression. This unexpected result is not secondary to a lack of CD8 ${ }^{+} \mathrm{T}$ cell epitopes in the immunizing HA (Deng et al., 1997) (unpublished observations).

\section{ACKNOWLEDGMENTS}

This work was supported in part by Public Health Service Grant AI 34946 and Training Grant AI 07349 from the National Institutes of Allergy and Infectious Diseases.

We are indebted to Dr. W. Gerhard for the provision of HAspecific T-cell lines and to Dr. N. Bhardwaj for training in the isolation of dendritic cells from lymph nodes. We thank Drs. R. Welsh and D. Feltquate for helpful discussions. We are indebted to H. Drake-Perrow for administrative assistance.

\section{REFERENCES}

ANDREE, C., SWAIN, W.F., PAGE, C.P., MACKLIN, M.D., SLAMA, J., HATZIS, D., and ERIKSSON, E. (1994). In vivo transfer and expression of a human epidermal grow th factor gene accelerates wound repair. Proc. Natl. Acad. Sci. USA 91, 12188-12192.

BANCHEREAU, J., and STEINMAN, R.M. (1998). Dendritic cells and the control of immunity. Nature 392, 245-252.

BURNS, W., BILLUPS, L.C., and NOTKINS, A.L. (1975). Thymus dependence of viral antigens. Nature 256, 654-665.

CASARES, S., INABA, K., BRUMEANU, T.D., STEINMAN, R.M., and BONA, C.A. (1997). Antigen presentation by dendritic cells after immunization with DNA encoding a major histocompatibility complex class II-restricted viral epitope. J. Exp. Med. 186, 14811486.

CHATTERGOON, M.A., ROBINSON, T.M., BOYER, J.D., and WEINER, D.B. (1998). Specific immune induction following DNAbased immunization through in vivo transfection and activation of macrophages/antigen-presen ting cells. J. Immunol. 160, 5707-5718.

CONDON, C., WATKINS, S.C., CELLUZZI, C.M., THOMPSON, K., and FALO, L.D. JR. (1996). DNA-based immunization by in vivo transfection of dendritic cells. Nature Med. 2, 1122-1128.

CORR, M., LEE, D.J., CARSON, D.A., and TIGHE, H. (1996). Gene vaccination with naked plasmid DNA: Mechanism of CTL priming. J. Exp. Med. 184, 1555-1560.

DENG, Y., YEWDELL, J.W., EISENLOHR, L.C., and BENNINK, J.R. (1997). MHC affinity, peptide liberation, T cell repertoire, and immunodominance all contribute to the paucity of MHC class I-restricted peptides recognized by antiviral CTL. J. Immunol. 158, $1507-$ 1515 .

DOE, B., SELBY, M., BARNETT, S., BAENZIGER, J., and WALKER, C.M. (1996). Induction of cytotoxic T lymphocytes by intramuscular immunization with plasmid DNA is facilitated by bone marrow-derived cells. Proc. Natl. Acad. Sci. USA 93, 8578-8583.

EISENBRAUN, M.D., FULLER, D.H., and HAYNES, J.R. (1993). Examination of parameters affecting the elicitation of humoral immune responses by particle bombardment-mediated genetic immunization. DNA Cell Biol. 12, 791-797.

FU, T.M., ULMER, J.B., CAULFIELD, M.J., DECK, R.R., FRIEDMAN, A., WANG, S., LIU, X., DONNELLY, J.J., and LIU, M.A. (1997). Priming of cytotoxic T lymphocytes by DNA vaccines: Requirement for professional antigen presenting cells and evidence for antigen transfer from myocytes. Mol. Med. 3, 362-371.

HARMS, J.S., and SPLITTER, G.M. (1995). Interferon-gam ma inhibits 
transgene expression driven by SV40 or CMV promoters but augments expression driven by the mammalian MHC I promoter. Hum. Gene Ther. 6, 1291-1297.

HATHCOCK, K. (1998). T cell enrichment by nonadherence to nylon wool. In Current Protocols in Immunology. J.E. Coligan, A.M. Kruisbeek, D.H. Marguiles, E.M. Shevack, and W. Strober, eds. (John Wiley and Sons, Inc., New York).

HENGGE, U.R., CHAN, E.F., FOSTER, R.A., WALKER, P.S., and VOGEL, J.C. (1995). Cytokine gene expression in epidermis with biological effects following injection of naked DNA. Nature Genet. 10, 161-166.

HOHLFELD, R., and ENGEL, A.G. (1994). The immunobiology of muscle. Immunol. Today 15, 269-274.

IWASAKI, A., TORRES, C.A., OHASHI, P.S., ROBINSON, H.L., and BARBER, B.H. (1997). The dominant role of bone marrow-derived cells in CTL induction following plasmid DNA immunization at different sites. J. Immunol. 159, 11-14.

JAKOB, T., WALKER, P.S., KRIEG, A.M., UDEY, M.C., and VOGEL, J.C. (1998). Activation of cutaneous dendritic cells by CpGcontaining oligodeoxynucleotid es: A role for dendritic cells in the augmentation of Th1 responses by immunostimulatory DNA. J. Immunol. 161, 3042-3049.

JOHANSSON, B.E., and KILBOURNE, E.D., (1993). Dissociation of influenza virus hemagglutinin and neuraminidase eliminates their intravirionic antigenic competition. J. Virol. 67, 5721-5723.

KLINMAN, D.M., SECHLER, J.M., CONOVER, J., GU, M., and ROSENBERG, A.S. (1998). Contribution of cells at the site of DNA vaccination to the generation of antigen-specific immunity and memory. J. Immunol. 160, 2388-2392.

LIU, M.A., FU, T.M., DONNELLY, J.J., CAULFIELD, M.J., and ULMER, J.B. (1998). DNA vaccines: Mechanisms for generation of immune responses. Adv. Exp. Med. Biol. 452, 187-191.

MOMBAERTS, P., CLARKE, A.R., RUDNICKI, M.A., IACOMINI, J., ITOHARA, S., LAFAILLE, J.J., WANG, L., ICHIKAWA, Y., JAENISCH, R., HOOPER, M.L., and TONEGAW A, S. (1992). Mutations in T-cell antigen receptor genes alpha and beta block thymocyte development at different stages [published erratum appears in Nature 1992;360:491]. Nature 360, 225-231.

PORGADOR, A., IRVINE, K.R., IWASAKI, A., BARBER, B.H., RESTIFO, N.P., and GERMAIN, R.N. (1998). Predominant role for directly transfected dendritic cells in antigen presentation to CD8+ $\mathrm{T}$ cells after gene gun immunization. J. Exp. Med. 188, 1075-1082.

RAZ, E., CARSON, D.A., PARKER, S.E., PARR, T.B., ABAI, A.M., AICHINGER, G., GROMKOWSKI, S.H., SINGH, M., LEW, D., YANKAUCKAS, M.A., BAIRD, S.M., and RHODES, G.H. (1994). Intradermal gene immunization: The possible role of DNA uptake in the induction of cellular immunity to viruses. Proc. Natl. Acad. Sci. USA 91, 9519-9523.

ROBINSON, H.L., FELTQUATE, D.M., MORIN, M.B., HAYNES, J.R., and WEBSTER, R.G. (1995). A new approach to immunization. Vaccines 95, 69-75.

ROBINSON, H.L., and PERTMER, T.M. (in press). DNA vaccines for viral infections: Basic studies and applications. Adv. Virus Res.

SARMIENTA, M., GLASEBROOK, A.L., and FITCH, F.W. (1980).
IgG or IgM monoclonal antibodies reactive with different determinants on the molecular complex bearing Lyt 2 antigen block T cellmediated cytolysis in the absence of complement. J. Immunol. 125, 2665-2672.

SCHERLE, P. (1988). An analysis of the function of influenza-specific CD4+ $\mathrm{T}$ cell clones in vivo. (The Wistar Institute, Philadelphia).

SCHERLE, P.A., and GERHARD, W. (1986). Functional analysis of influenza-specific helper $\mathrm{T}$ cell clones in vivo: $\mathrm{T}$ cells specific for internal viral proteins provide cognate help for B cell responses to hemagglutinin. J. Exp. Med. 164, 1114-1128.

SPARWASSER, T., KOCH, E.S., VABULAS, R.M., HEEG, K., LIPFORD, G.B., ELLWART, J.W., and WAGNER, H. (1998). Bacterial DNA and immunostimula tory $\mathrm{CpG}$ oligonucleotides trigger maturation and activation of murine dendritic cells. Eur. J. Immunol. 28, 2045-2054.

STINGL, G. (1990). Dendritic cells of the skin. Dermatol. Clin. 8, 673679.

TORRES, C.A., IWASAKI, A., BARBER, B.H., and ROBINSON, H.L. (1997). Differential dependence on target site tissue for gene gun and intramuscular DNA immunizations. J. Immunol. 158, 45294532 .

WARFEL, A.H., THORBECKE, G.J., and BELSITO, D.V. (1993). Langerhans cells as outposts of the dendritic cell system. Adv. Exp. Med. Biol. 329, 469-480.

WILDE, D.M., MARRACK, P., KAPPLER, J., DIALYNAS, D.P., and FITCH, F.W. (1983). Evidence implicating L3T4 in class II MHC antigen reactivity: Monoclonal antibody GK1.5 (anti-L3T4a) blocks class II MHC antigen-specific proliferation, release of lymphokines, and binding by cloned murine helper T lymphocyte lines. J. Immunol. 131, 2178-2183.

WILLIAMS, R.S., JOHNSTON, S.A., RIEDY, M., DE VIT, M.J., MCELLIGOTT, S.G., and SANFORD, J.C. (1991). Introduction of foreign genes into tissues of living mice by DNA-coated microprojectiles. Proc. Natl. Acad. Sci. USA 88, 2726-2730.

WINEGAR, R.A., MONFORTE, J.A., SUING, K.D., O'LOUGHLIN, K.G., RUDD, C.J., and MACGREGOR, J.T. (1996). Determination of tissue distribution of an intramuscular plasmid vaccine using PCR and in situ DNA hybridization. Hum. Gene Ther. 7, 2185-2194.

WOLFF, J.A., MALONE, R.W., WILLIAMS, P., CHONG, W., ACSADI, G., JANI, A., and FELGNER, P.L. (1990). Direct gene transfer into mouse muscle in vivo. Science 247, 1465-1468.

Address reprint requests to: Dr. Harriet L. Robinson Yerkes Regional Primate Research Center 954 Gatewood Road NE Atlanta, GA 30329

E-mail: hrobins@ rmy.emory.edu

Received for publication October 16, 1999; received in revised form December 20, 1999; accepted December 22, 1999. 